\title{
INTRAVASCULAR CATHETERIZATION STUDIES OF BRONCHIAL ASTHMA. I. HISTAMINE LEVELS IN ARTERIAL AND MIXED VENOUS BLOOD OF ASTHMATIC PATIENTS BEFORE AND DURING INDUCED ATTACKS ${ }^{1,2}$
}

\author{
By BRAM ROSE, IAN RUSTED, AND J. ALBERT FOWNES \\ (From the McGill University Clinic, the Department of Medicine and Radiology, \\ the Royal Victoria Hospital, Montreal, Canada)
}

(Submitted for publication November 7, 1949; accepted, May 29, 1950)

The relation of histamine to asthma has long been controversial and many claims have been made that this metabolite may partly be responsible for the symptoms occurring during an attack. Much of the evidence for these claims is based upon observations on the levels of total blood histamine before and during attacks. For example, Randolph and Rackemann (1) found an increase of histamine in the blood during asthmatic attacks in seven out of nine patients. On the other hand Rose (2) was unable to demonstrate any consistent increase in the blood histamine during various forms of asthma. These observations were based on samples of blood taken from the antecubital vein which represents arterial blood that has passed through the vascular bed in the hand and forearm. As such, it is not truly representative of the venous blood reaching the lungs, which is a mixture of the return flow from all the parenchymal organs. Since the possibility existed that histamine may be released elsewhere in the body and have its effect only on reaching the pulmonary vascular bed, it was felt that the blood histamine content in the pulmonary artery might provide more accurate information regarding the levels of histamine and their possible significance in the production of bronchiolar spasm. Similarly, on the chance that histamine might be released from the lungs themselves during asthma, blood samples for analysis were taken from the femoral artery at the same time.

\section{METHODS}

Studies were carried out by means of right-sided cardiac catheterization during which blood was obtained from the pulmonary artery in the quiescent state and following the

1 This work was supported by a Grant-in-Aid from the National Research Council, Ottawa.

2 Part of this work is aided by a grant from the Ciba Company Limited, Montreal. induction of an asthma-like attack using either histamine, mecholyl, or, in the case of suitable patients, the inhalation of a specific allergen. ${ }^{3}$ In addition, samples were taken simultaneously from the femoral artery by means of an indwelling arterial needle. ${ }^{4}$

The subjects were patients attending the Allergy Clinic of the Royal Victoria Hospital. All had been completely investigated from a general medical standpoint as well as for their allergic manifestations. Before catheterization was attempted an assessment was made of pulmonary function, including vital capacity and maximum breathing capacity, and the response to histamine, mecholyl or a specific pollen. A preliminary investigation of this nature was also carried out on all controls. These studies allowed the subject to become acquainted with the apparatus and to experience an induced attack. This was felt to be important in order to reduce anxiety during the catheterization procedure and ensure as near a basal state as possible since no sedation was used. On the basis of chest X-rays and electrocardiograms or clinical evidence, all patients with evidence of coronary artery disease or cardiac arrhythmias were eliminated from the series.

Cardiac catheterization was performed essentially as described by Warren and Cournand (3). The median cubital vein of the left arm was preferred because, as pointed out by Forssmann in his original article (4), the curve is more gradual from the left innominate vein to the superior vena cava than when approaching from the right. In about one third of the cases the pulmonary artery could not be catheterized. In one of the cases the tip of the catheter was allowed to remain in the right ventricle, and in five the right auricle.

Following the introduction of the cardiac catheter, a Cournand needle was inserted into the right femoral artery, and control blood samples of mixed venous from the catheter, and arterial via the needle were then obtained. Further samples were collected at various intervals during an artificially induced asthma-like state and

3 The pollen extract given in all cases in this series was the $1: 33$ sterile phosphate buffered Ragweed solution, containing alcohol $14 \%$ by volume, and $0.5 \%$ phenol as preservative, prepared by the Arlington Chemical Company, of Yonkers, N. Y.

4 The earlier catheterizations were performed by Dr. A. L. Johnson, whose generous assistance has been responsible for the solution of many technical difficulties. 
following the use of certain therapeutic drugs. The attacks were produced as follows:

A) Six patients received histamine diphosphate (1 mgm. subcutaneously),

B) Eight patients received mecholyl (acetyl beta methyl choline) (10 mgm. subcutaneously),

C) Two patients were given inhalations of ragweed extract $(1: 33$ in saline and $14 \%$ alcohol with $0.5 \%$ phenol as preservative). The number of inhalations required to produce an attack varied from four to 16.

Catheterization was also performed in five normal male volunteers. These were given histamine, and when symptoms had subsided, mecholyl in the same dosages as were used for patients with clinical asthma were administered.

The blood samples were assayed for their histamine content by the method of Barsoum and Gaddum (5), as modified by Code (6). The normal values for peripheral venous blood by this method vary from $2.0-7.0 \gamma$ of histamine per $100 \mathrm{cc}$. whole blood (7). All values are expressed as histamine base.

\section{RESULTS}

\section{A. General}

Neither histamine nor mecholyl produced any obvious respiratory changes in the control group of subjects. A few remarked on a feeling of mild constriction in the chest and a desire to breathe more deeply.

The group of asthmatic patients varied in their response. Histamine injection produced a moderate transient increase in respiration with occasional audible râles in the chest. These attacks were over in five to ten minutes and required no medication. A severe attack was precipitated in patient 20. Within two minutes he was markedly dyspnoeic and there were many audible expiratory râles in the chest. The attack was terminated 14 minutes after the injection of histamine by the administration of $2 \mathrm{cc}$. Antistine intravenously. The injection of mecholyl produced more consistent effects. Dyspnoea clinically similar to moderate asthma occurred, and râles were audible in patient 12 . In no instance was cyanosis evident. The more severe attacks produced by either histamine or mecholyl were thought to be quite similar to spontaneous asthmatic attacks by the patients themselves.

In distinction to the above, attacks produced by the inhalation of ragweed extract took longer to come on (seven to ten minutes), were much more profound and lasted a longer time unless termi- nated. They were also associated with cyanosis and typical signs in the chest.

The degree of asthma was in all cases assessed by respiratory function studies, which confirmed the production of a significant decrease in Maximum Breathing Capacity and Vital Capacity.

\section{B. Blood histamine values}

In Table I, control venous and arterial blood histamine levels are shown in five normal subjects and 12 asthmatic patients. It will be seen that there was little difference on the average between histamine content of mixed venous or arterial blood in the control subjects. However, the arterial blood histamine content in 11 of the asthmatic patients was consistently higher than that of the mixed venous blood taken at the same time. In the 12th (patient 20) arterial blood histamine was lower. Furthermore, the average histamine content of both venous and arterial blood was lower in the normal subjects $(1.9 \gamma / 100 \mathrm{cc}$.) as compared to that of the group of asthmatics (3.73 and $4.2 \gamma / 100 \mathrm{cc}$.).

Table II shows the effect of the administration of histamine or mecholyl on the blood histamine level of the five normal subjects. It will be seen that no appreciable alterations were produced, ex-

TABLE I

Control blood histamine levels in normal and asthmatic subjects

\begin{tabular}{|c|c|c|c|c|}
\hline \multirow{2}{*}{$\begin{array}{l}\text { Subject } \\
\text { Normal }\end{array}$} & \multirow{2}{*}{$\begin{array}{c}\text { Case no. } \\
\\
19 \\
21 \\
22 \\
23 \\
25\end{array}$} & \multicolumn{2}{|c|}{$\begin{array}{l}\text { Blood histamine } \\
\gamma / 100 \text { cc. }\end{array}$} & \multirow{2}{*}{$\begin{array}{c}\text { Difference } \\
0 \\
+0.8 \\
+0.5 \\
-0.2 \\
-1.0\end{array}$} \\
\hline & & $\begin{array}{c}\text { Venous } \\
2.8 \\
1.0 \\
2.0 \\
1.5 \\
2.2\end{array}$ & $\begin{array}{c}\text { Arterial } \\
2.8 \\
1.8 \\
2.5 \\
1.3 \\
1.2\end{array}$ & \\
\hline & Average & 1.9 & 1.9 & +0.1 \\
\hline \multirow[t]{2}{*}{ Asthmatic } & $\begin{array}{r}1 \\
2 \\
5 \\
8 \\
9 \\
10 \\
11 \\
12 \\
13 \\
16 \\
17 \\
20\end{array}$ & $\begin{array}{r}2.7 \\
5.0 \\
3.0 \\
3.1 \\
3.2 \\
3.5 \\
6.0 \\
0.4 \\
1.0 \\
2.0 \\
2.9 \\
12.0\end{array}$ & $\begin{array}{r}3.0 \\
5.3 \\
4.0 \\
3.3 \\
4.4 \\
4.5 \\
6.4 \\
1.2 \\
1.5 \\
2.5 \\
3.7 \\
11.0\end{array}$ & $\begin{array}{l}+0.3 \\
+0.3 \\
+1.0 \\
+0.2 \\
+1.2 \\
+1.0 \\
+0.4 \\
+0.8 \\
+0.5 \\
+0.5 \\
+0.8 \\
-1.0\end{array}$ \\
\hline & Average & 3.73 & 4.2 & +0.4 \\
\hline
\end{tabular}


TABLE II

Effect of histamine and mecholyl on blood histamine of normals

\begin{tabular}{|c|c|c|c|c|c|}
\hline Case no. & Site of catheter & $\begin{array}{l}\text { Time in minutes after } \\
\text { injections }\end{array}$ & \multicolumn{2}{|c|}{$\begin{array}{l}\text { Histamine levels } \\
\gamma / 100 \text { cc. }\end{array}$} & Clinical summary \\
\hline 19 & $\begin{array}{l}\text { Pulmonary } \\
\text { artery }\end{array}$ & $\begin{array}{l}\text { Control } \\
\text { After histamine } \\
2^{\prime} \\
6^{\prime} \\
\text { After mecholyl } \\
2^{\prime} \\
6^{\prime}\end{array}$ & $\begin{array}{c}\text { Venous } \\
2.8 \\
2.0 \\
2.5 \\
2.3 \\
2.5\end{array}$ & $\begin{array}{c}\text { Arterial } \\
2.8 \\
2.8 \\
2.5 \\
\\
2.5 \\
2.8\end{array}$ & $\begin{array}{l}\text { Male, aged 26. Mother had bronchial asthma. } \\
\text { Histamine injection produced the expected } \\
\text { effects (flushing and headache). Mecholyl } \\
\text { caused salivation and perspiration. }\end{array}$ \\
\hline 21 & $\begin{array}{l}\text { Right } \\
\text { atrium }\end{array}$ & $\begin{array}{l}\text { Control } \\
\text { After mecholyl } \\
2^{\prime} \\
5^{\prime}\end{array}$ & $\begin{array}{l}1.0 \\
1.0 \\
1.0\end{array}$ & $\begin{array}{l}1.8 \\
1.2 \\
1.0\end{array}$ & $\begin{array}{l}\text { Male, aged 23. Past history of malaria. } \\
\text { Subject experienced a pyrogenic reaction dur- } \\
\text { ing the procedure. Mecholyl produced the } \\
\text { usual effects. }\end{array}$ \\
\hline 22 & $\begin{array}{l}\text { Pulmonary } \\
\text { artery }\end{array}$ & $\begin{array}{l}\text { Control } \\
\text { After mecholyl } \\
2^{\prime} \\
5^{\prime} \\
\text { After histamine } \\
2^{\prime} \\
5^{\prime}\end{array}$ & $\begin{array}{l}2.0 \\
2.0 \\
2.5 \\
4.0 \\
4.0\end{array}$ & $\begin{array}{l}2.5 \\
2.0 \\
1.8 \\
\\
3.0 \\
7.5\end{array}$ & $\begin{array}{l}\text { Male, aged } 25 . \text { Mecholyl caused salivation } \\
\text { and perspiration, with very slight tightness in } \\
\text { chest. No change in vital capacity. Hista- } \\
\text { mine injection caused headache. }\end{array}$ \\
\hline 23 & $\begin{array}{l}\text { Pulmonary } \\
\text { artery }\end{array}$ & $\begin{array}{l}\text { Control } \\
\text { After histamine } \\
2^{\prime} \\
4^{\prime} \\
11^{\prime} \\
\text { After mecholyl } \\
2^{\prime}\end{array}$ & $\begin{array}{l}1.5 \\
1.2 \\
1.0 \\
1.1 \\
1.2\end{array}$ & $\begin{array}{l}1.3 \\
1.3 \\
1.3 \\
1.0 \\
1.1\end{array}$ & $\begin{array}{l}\text { Male, aged } 22 . \text { Nausea and vomiting oc- } \\
\text { curred during the procedure. Histamine } \\
\text { produced flushing of the face and made the } \\
\text { patient feel better. Mecholyl caused a slight } \\
\text { increase in salivation and perspiration. }\end{array}$ \\
\hline 25 & $\begin{array}{l}\text { Right } \\
\text { atrium }\end{array}$ & $\begin{array}{l}\text { Control } \\
\text { After histamine } \\
2^{\prime} \\
6^{\prime} \\
10^{\prime} \\
\text { Plasma values: } \\
\text { Control } \\
2^{\prime}\end{array}$ & 1.0 & $\begin{array}{l}1.2 \\
2.0 \\
2.2 \\
2.5 \\
\\
0.7 \\
1.0\end{array}$ & $\begin{array}{l}\text { Male, aged } 34 \text {. Histamine injection pro- } \\
\text { duced flushing and a marked tachycardia. }\end{array}$ \\
\hline
\end{tabular}

cept in the case of patient 22. Here the arterial blood histamine was $2.5 \gamma / 100 \mathrm{cc}$. and rose to $3 \gamma$ at two minutes and $7.5 \gamma$ at five minutes after the administration of histamine. Mecholyl produced no change.

Table III shows the effect of the administration of histamine to a group of six asthmatic patients. The changes in the venous blood histamine were small and inconsistent, a rise occurring in one (No. 2), a fall in two (Nos. 8 and 11) and no change in two (Nos. 1 and 5). Similar results were obtained in the arterial blood histamine values, a rise occurring in three, and a reduction in two. Thus, with the exception of patient 20 , in whom the blood histamine values were high, all of the remaining subjects had blood histamine levels which did not vary markedly or consistently.

The effect of the administration of mecholyl to eight patients, all of whom were subject to asthma, is shown in Table IV. The histamine content of the venous blood rose in six patients and fell in two. The histamine content of the arterial blood samples followed the same trend. In patients 5 and 6 some of the arterial samples were unobtainable owing to technical difficulties. It is of interest that the venous blood histamine values in patient 6 were very much lower than is usually found. In patient 5 a rise occurred at the five minute interval, with a return to normal at the 19 minute interval.

The results obtained on two patients with pollen asthma are shown in Table V. Preliminary studies during which asthma had been induced by the inhalation of ragweed aerosol showed a marked reduction in respiratory function. In both patients asthma was again produced by the same method during catheterization. As will be observed in patient 17 , although severe asthma de- 
TABLE III

Effect of histamine induced asthma on blood histamine levels

\begin{tabular}{|c|c|c|c|c|c|}
\hline Case no. & Site of catheter & $\begin{array}{l}\text { Time in minutes } \\
\text { after injections }\end{array}$ & \multicolumn{2}{|c|}{$\begin{array}{l}\text { Histamine levels } \\
\gamma / 100 c c .\end{array}$} & Clinical summary \\
\hline 1 & $\begin{array}{l}\text { Pulmonary } \\
\text { artery }\end{array}$ & $\begin{array}{l}\text { Control } \\
4^{\prime}\end{array}$ & $\begin{array}{l}\text { Venous } \\
2.7 \\
2.7\end{array}$ & $\begin{array}{l}\text { Arterial } \\
3.0 \\
4.2\end{array}$ & $\begin{array}{l}\text { Male, aged 44. Intrinsic asthma; chronic bi- } \\
\text { lateral maxillary sinusitis. Tbc. right apex, ap- } \\
\text { parently healed. Emphysema; bronchiectasis, } \\
\text { left lower lobe. Only } 0.5 \text { mgm. histamine used } \\
\text { to produce a mild attack during catheterization. }\end{array}$ \\
\hline 2 & $\begin{array}{l}\text { Pulmonary } \\
\text { artery }\end{array}$ & $\begin{array}{l}\text { Control } \\
3^{\prime} \\
5^{\prime}\end{array}$ & $\begin{array}{l}5.0 \\
6.3\end{array}$ & $\begin{array}{l}5.3 \\
6.0\end{array}$ & $\begin{array}{l}\text { Male, aged } 51 \text {. Intrinsic asthma; emphysema. } \\
\text { Histamine injection produced flushing of face } \\
\text { and slight degree of dyspnoea. }\end{array}$ \\
\hline 5 & $\begin{array}{l}\text { Pulmonary } \\
\text { artery }\end{array}$ & $\begin{array}{l}\text { Control } \\
4^{\prime}\end{array}$ & $\begin{array}{l}3.0 \\
3.0\end{array}$ & $\begin{array}{l}4.0 \\
2.3\end{array}$ & $\begin{array}{l}\text { Male, aged } 59 . \text { Intrinsic asthma; emphysema. } \\
\text { Histamine injection caused flushing of the face } \\
\text { and mild dyspnoea. }\end{array}$ \\
\hline 8 & $\begin{array}{l}\text { Pulmonary } \\
\text { artery }\end{array}$ & $\begin{array}{l}\text { Control } \\
3^{\prime}\end{array}$ & $\begin{array}{l}3.1 \\
2.2\end{array}$ & 3.3 & $\begin{array}{l}\text { Female, aged 20. Extrinsic asthma, primarily } \\
\text { (cat dander, ragweed and grasses). Intrinsic } \\
\text { factors also present. Histamine injection pro- } \\
\text { duced only flushing of face and headache. }\end{array}$ \\
\hline 11 & $\begin{array}{l}\text { Pulmonary } \\
\text { artery }\end{array}$ & $\begin{array}{l}\text { Control } \\
6^{\prime} \\
10^{\prime}\end{array}$ & $\begin{array}{l}6.0 \\
5.0\end{array}$ & $\begin{array}{l}6.4 \\
5.2\end{array}$ & $\begin{array}{l}\text { Male, aged 19. Extrinsic asthma since age } 2 \\
\text { Bacterial allergy now a factor. Injection pro- } \\
\text { duced flushing of facial region and a slight amount } \\
\text { of tightness in chest. }\end{array}$ \\
\hline 20 & Right atrium & $\begin{array}{l}\text { Control } \\
2^{\prime} \\
4^{\prime} \\
10^{\prime} \\
15^{\prime}\end{array}$ & $\begin{array}{r}12.0 \\
11.0 \\
13.5 \\
13.5 \\
7.0\end{array}$ & $\begin{array}{r}11.0 \\
11.0 \\
13.0 \\
13.5 \\
9.5\end{array}$ & $\begin{array}{l}\text { Male, aged 28. Bronchial asthma and eczema } \\
\text { since childhood. Tbc. in 1943, treated by } \\
\text { thoracoplasty in 1947, severe attack produced } \\
\text { See text for further details regarding this patient } \\
\text { Last samples were taken one min. following the } \\
\text { injection of an antihistaminic via the catheter. }\end{array}$ \\
\hline
\end{tabular}

veloped, venous and arterial blood samples taken at the height of the attack showed little change in the histamine levels. Unfortunately only mixed venous samples were obtained from patient 24 . Although there is a variation of the venous blood histamine content, taken from the right auricle in this case, the rise would not seem to be of great significance. The injection of an antihistamine (Antistine) through the catheter affected neither the blood histamine nor the patient's symptoms.

\section{DISCUSSION}

The above results confirm the observation that patients with asthma may be precipitated into an asthmatic attack either by the injection of histamine or mecholyl whereas normal individuals do not so react (8). Though the series is a small one, there appears to be a difference in the blood histamine levels of asthmatic patients and nonallergic subjects in that the level of blood histamine at rest is slightly higher in the asthmatic. In this connection, it is of interest to note that the tissue histamine of patients with various forms of allergy such as asthma or eczema may be many times higher than that found in normal subjects. Patient 16 is such an example, for two weeks after catheterization the left lower lobe was removed for bronchiectasis. An assay of the upper portions of the removed lung tissue showed a histamine content of $106 \gamma / \mathrm{gm}$., whereas the average histamine content of normal lung is $20 \gamma / \mathrm{gm}$. (9). In addition, asthmatics in particular excrete large amounts of histamine in the urine (10). In keeping with the thesis that histamine metabolism is disturbed in the asthmatic is the finding that arterial histamine is somewhat higher than the venous blood histamine as shown in Table I, whereas there is little difference in these two values in the normal subjects. A larger series of determinations in normals would be required to establish this, however. This could be interpreted as an indication of a lowered histaminase activity of lung tissue, since this organ is known to be rich in this enzyme (11).

Since the procedure outlined above affords a means of studying the blood just before its entry 
TABLE IV

Effect of mecholyl induced asthma on blood histamine levels

\begin{tabular}{|c|c|c|c|c|c|}
\hline Case no. & Site of catheter & $\begin{array}{l}\text { Time in minutes } \\
\text { after injections }\end{array}$ & \multicolumn{2}{|c|}{$\begin{array}{l}\text { Histamine levels } \\
\gamma / 100 \text { cc. }\end{array}$} & Clinical summary \\
\hline 2 & $\begin{array}{l}\text { Pulmonary } \\
\text { artery }\end{array}$ & $\begin{array}{l}\text { Control } \\
4^{\prime} \\
6^{\prime}\end{array}$ & $\begin{array}{l}\text { Venous } \\
5.0 \\
6.0\end{array}$ & $\begin{array}{c}\text { Arterial } \\
5.3 \\
8.0\end{array}$ & $\begin{array}{l}\text { Male, aged } 51 \text {. Intrinsic asthma; emphysema. } \\
\text { Iniection produced salivation, perspiration and } \\
\text { moderately severe asthma. }\end{array}$ \\
\hline 5 & $\begin{array}{l}\text { Pulmonary } \\
\text { artery }\end{array}$ & $\mathbf{3}^{\prime}$ & $\begin{array}{l}3.0 \\
3.8\end{array}$ & 4.0 & $\begin{array}{l}\text { Male, aged } 59 . \text { Intrinsic asthma; emphysema. } \\
\text { Injection caused salivation, coughing and ex- } \\
\text { pectoration, with moderately severe asthma. }\end{array}$ \\
\hline 6 & $\begin{array}{l}\text { Pulmonary } \\
\text { artery }\end{array}$ & $\underset{4^{\prime}}{\text { Control }}$ & $\begin{array}{l}0.6 \\
0.4\end{array}$ & & $\begin{array}{l}\text { Female, aged } 34 \text {. Bronchial asthma, primarily } \\
\text { intrinsic. Injection caused salivation, perspira- } \\
\text { tion and moderately severe asthma. }\end{array}$ \\
\hline 9 & Right atrium & $\underset{6^{\prime}}{\text { Control }}$ & $\begin{array}{l}3.2 \\
4.5\end{array}$ & $\begin{array}{l}4.4 \\
4.0\end{array}$ & $\begin{array}{l}\text { Male, aged } 39 . \text { Bronchial asthma of mixed (in- } \\
\text { trinsic and extrinsic) origin. Minimal tbc. right } \\
\text { apex, arrested; kyphosis. Injection caused } \\
\text { salivation, perspiration and slight asthma. }\end{array}$ \\
\hline 10 & Right ventricle & $\begin{array}{l}\text { Control } \\
8^{\prime} \\
18^{\prime}\end{array}$ & $\begin{array}{l}3.5 \\
2.3\end{array}$ & $\begin{array}{l}4.5 \\
4.1 \\
4.1\end{array}$ & $\begin{array}{l}\text { Male, aged } 63 \text {. Intrinsic asthma; emphysema. } \\
\text { Injection caused a great deal of salivation, } \\
\text { perspiration, coughing and tightness in the chest. }\end{array}$ \\
\hline 12 & $\begin{array}{l}\text { Pulmonary } \\
\text { artery }\end{array}$ & $\underset{5^{\prime}}{\text { Control }}$ & $\begin{array}{l}0.4 \\
1.8\end{array}$ & $\begin{array}{l}1.2 \\
3.0\end{array}$ & $\begin{array}{l}\text { Female, aged } 26 . \text { Bronchial asthma of five } \\
\text { years'duration, considered as intrinsic; eczema. } \\
\text { Injection produced salivation, perspiration and } \\
\text { moderately severe asthma with râles clearly } \\
\text { audible. }\end{array}$ \\
\hline 13 & $\begin{array}{l}\text { Pulmonary } \\
\text { artery }\end{array}$ & $\begin{array}{l}\text { Control } \\
5^{\prime} \\
19^{\prime}\end{array}$ & $\begin{array}{l}1.0 \\
1.8\end{array}$ & $\begin{array}{l}1.5 \\
3.0 \\
1.5\end{array}$ & $\begin{array}{l}\text { Female, aged } 49 \text {. Bronchial asthma of mixed } \\
\text { type (ingestants, bacteria and a definite psycho- } \\
\text { logical factor). Chronic maxillary sinusitis and } \\
\text { bronchitis. Injection of } 7 \text { mgm. mecholyl } \\
\text { seemed to increase the slight amount of dyspnoea } \\
\text { already present. }\end{array}$ \\
\hline 16 & $\begin{array}{l}\text { Pulmonary } \\
\text { artery }\end{array}$ & $\begin{array}{l}\text { Control } \\
11^{\prime}\end{array}$ & $\begin{array}{l}2.0 \\
3.0\end{array}$ & $\begin{array}{l}2.5 \\
3.0\end{array}$ & $\begin{array}{l}\text { Male, aged } 26 . \text { Chronic maxillary sinusitis, } \\
\text { nasal polypi; bronchiectasis; intrinsic bronchial } \\
\text { asthma since } 1943 \text {. Injection produced saliva- } \\
\text { tion, perspiration abdominal cramps and very } \\
\text { slight tightness in chest, this last symptom being } \\
\text { also transient (two to three mins. duration). }\end{array}$ \\
\hline
\end{tabular}

TABLE $V$

Effect of ragweed inhalations on blood histamine

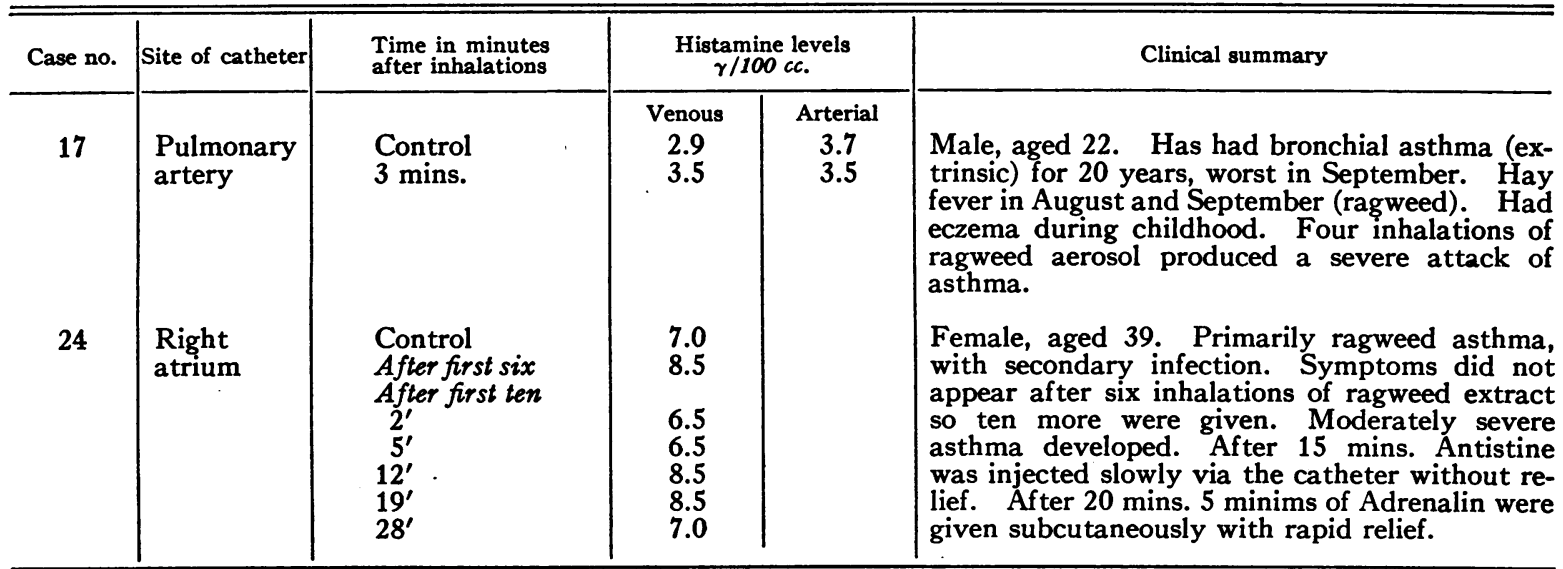


into, as well as after it has been perfused through the pulmonary vascular bed, it was felt that were histamine released in any quantity during asthma, one should be able to detect a rise in either the venous or arterial blood samples. It is apparent from the results obtained that no consistent increase could be demonstrated. This finding does not invalidate the theory that histamine might be partly responsible, however, since attacks induced by the subcutaneous injection of histamine itself were not accompanied by any increase in the histamine levels of the various samples. It is possible that the increments involved are not demonstrable by the method used. Mention should be made of the fact as well that there are highly active antihistamine mechanisms in the blood. Evidence for this was presented in 1940 when it was shown that the intravenous infusion of histamine in the antecubital vein of one arm in quantities sufficient to produce marked flushing and lowering of blood pressure, were accompanied by a lowering of the histamine content of the blood taken from the antecubital vein of the opposite arm (12).

These results may be criticized on the basis that active or plasma histamine was not measured as it is possible that a shift of histamine may occur from the cells into the plasma without alteration of the whole blood value, and still give rise to symptoms (13). However, in other studies on cases of hypersensitivity to cold, a rise in the plasma histamine was usually accompanied by an increase in the total blood histamine (14).

It has been reported by Serafini (15) that histamine induced asthma is accompanied by an increase in the histamine content of the whole blood, whereas no increase occurs when the injection is given to non-allergic subjects. Serafini later notes that the blood histamine values varied (being increased, normal or reduced) during asthmatic attacks produced by the injection. This statement seems to be somewhat at variance with the first finding that a rise occurred in most cases only during the interval preceding the onset of symptoms, which is usually about two minutes after the injection. An examination of Serafini's results shows that this occurred in less than one third of his cases. In some of these, and in all others, the elevations were spread out over several minutes and occasionally persisted to the end of the recorded observations 20 minutes after the injection. This means, therefore, that the greatest elevations in blood histamine must have occurred during the time when symptoms were being experienced and over the period of time similar to that during which our own observations were made. It must be noted that the dose of histamine administered by Serafini $(1 \mathrm{mgm}$. histamine hydrochloride) is about twice that used in the present investigation $(1 \mathrm{mgm}$. histamine phosphate) which may account partly for the fact that our results do not confirm his. Nevertheless, in a small group of patients with asthma complicated by pulmonary tuberculosis, findings of a different nature have been observed (16) for the subcutaneous injection of $0.5 \mathrm{mgm}$. of histamine phosphate induced a severe attack of asthma, and a very marked rise in the blood histamine. Patient 20 in the present series was such an example. In 1943 prior to the development of tuberculosis, the injection of histamine produced no rise in the peripheral blood histamine although symptoms of asthma were induced. In 1947, after a thoracoplasty and two years after the diagnosis of tuberculosis was established, an injection of histamine produced symptoms as before, but this time, there was a marked rise in the blood histamine. This was interpreted at the time that the lungs were incapable of dealing with excess amounts of histamine which may have accounted for the marked increase in the blood. It seemed too that an additional release of histamine must be occurring from some source. It is possible that the less marked increase in the blood histamine observed in this patient during the present studies could be related to the fact that this tuberculosis is now quiescent.

On the basis of present results it would seem that injections of histamine (or mecholyl) cause only minor changes in whole blood histamine in most asthmatics, the changes usually encountered being no greater than those which may occasionally be found in normals. Since there is no significant increase in the venous or arterial blood histamine following the induction of an asthmalike state by the administration of histamine itself, failure to demonstrate an increase of this substance in the blood of asthmatic patients following attacks induced by mecholyl, or in the case of suitable subjects, ragweed inhalation, does not invalidate the theory that histamine may be a factor in the pro- 
duction of clinical asthma. However, the failure of antihistamine compounds to control clinical asthma, and their ability to prevent histamine induced attacks as shown by Schiller and Lowell (17) is evidence to the contrary.

\section{SUMMARY}

1. A group of asthmatic patients and five normal subjects were studied by means of cardiac catheterization. Blood samples for histamine analysis were obtained from the femoral artery, and either the right auricle, right ventricle or pulmonary artery, during a control period and following the induction of an asthma-like state.

2. The control blood histamine values were higher in the group of asthmatics as compared to those of the normal subjects.

3. Whereas there was little difference between venous and arterial blood histamine levels in the normal subjects, the arterial samples of the asthmatic patients were higher than the corresponding venous samples.

4. The administration of histamine or mecholyl to the group of normals did not produce asthmalike symptoms. In only one case was there any appreciable change in arterial or mixed venous blood histamine content.

5. In the group of asthmatics, although asthmalike symptoms were produced, the changes in both the arterial and venous blood histamine. contents were not significantly different from those obtained on control subjects.

6. The induction of clinical asthma in two ragweed sensitive patients was not accompanied by a significant increase in the blood histamine values.

7. Based on the above observations, it is concluded that a rise in the whole venous or arterial blood histamine is not an accompanying change during the induction of an asthma-like state following histamine or mecholyl injection, or during clinical asthma due to ragweed inhalations.

8. These findings, while they do not support the theory that histamine may be a factor in the pro- duction of asthma, are not sufficient to invalidate this theory.

\section{BIBLIOGRAPHY}

1. Randolph, T. G., and Rackemann, F. M., The blood histamine level in asthma and in eosinophilia. J. Allergy, 1941, 12, 450.

2. Rose, B., Studies on blood histamine in patients with allergy. II. Alterations in the blood histamine in patients with allergic disease. J. Clin. Invest., 1941, 20, 419.

3. Warren, J. V. (Comment by A. F. Cournand), Determination of cardiac output by right heart catheterization, in: Methods in Medical Research. The Year Book Publishers, Inc., Chicago, 1948, Vol. I, p. 224.

4. Forssmann, W., Die Sondierung des rechten Herzens. Klin. Wchnschr., 1929, 8, 2085.

5. Barsoum, G. S., and Gaddum, J. H., The pharmacological estimation of adenosine and histamine in the blood. J. Physiol., 1935, 85, 1.

6. Code, C. F., The quantitative estimation of histamine in the blood. J. Physiol., 1937, 89, 257.

7. Rose, B., The role of histamine in anaphylaxis and allergy. Am. J. Med., 1947, 3, 545.

8. Curry, J. J., Comparative action of acetyl-beta-methyl choline and histamine on the respiratory tract in normals, patients with hay fever, and subjects with bronchial asthma. J. Clin. Invest., 1947, 26, 430.

9. Rose, B., Baxter, H. W., and Entin, M., The histamine content of tissues. To be published.

10. Rose, B., Pare, J. A. P., Pump, K., and Stanford, R. L., Preliminary report on adrenocorticotrophic hormone (ACTH) in asthma. Canad. M. A. J., $1950,62,6$.

11. Best, C. H., Disappearance of histamine from autolysing lung tissue. J. Physiol., 1929, 67, 256.

12. Rose, B., Production of symptoms by subcutaneous injection of histamine without increase of the blood histamine. Science, 1940, 92, 454.

13. Staub, H., Histaminämie nach Adrenalin. Experientia, 1946, 2, 29.

14. Rose, B., Studies on the role of histamine in hypersensitivity to cold. J. Clin. Invest., 1948, 27, 553.

15. Serafini, U., Studies on histamine and histamine antagonists. J. Allergy, 1948, 19, 256.

16. Rose, B., Unpublished results.

17. Schiller, I. W., and Lowell, F. C., The effect of drugs in modifying the response to asthmatic subjects to inhalation of pollen extracts as determined by vital capacity measurements. Ann. Allergy, 1947, 5, 564. 